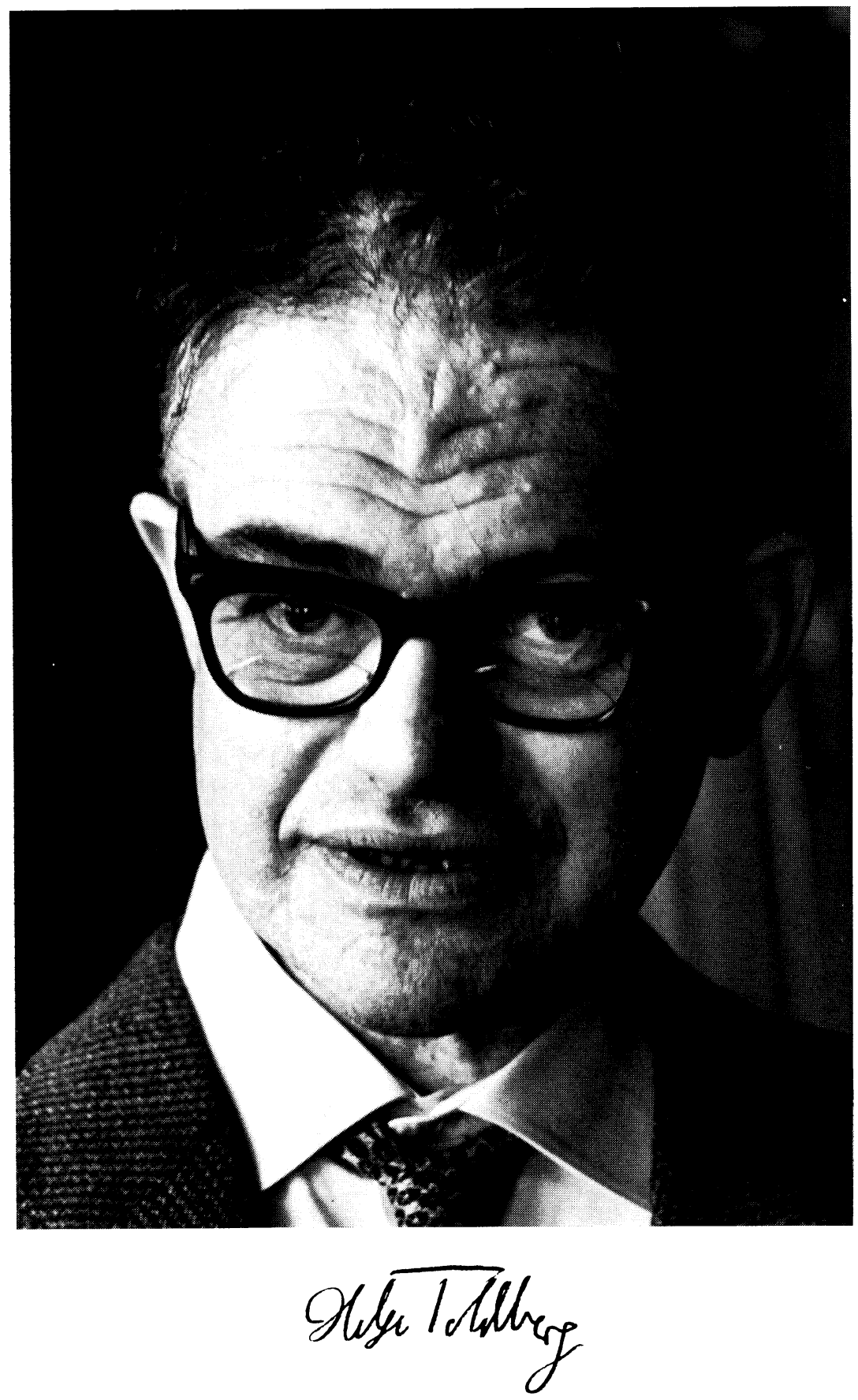




\section{Helge Toldberg}

2I. APRIL I9I3-29. JUNI I964

Det gjorde et dybt indtryk på deltagerne i den Femte internationale studiekonference $\mathrm{i}$ skandinavisk litteratur (der afholdtes $\mathrm{i}$ London den 6.-ro. juli i år) ved åbningsmødet at erfare, at en af de anmeldte foredragsholdere, dr. phil. Helge Toldberg var død i London søndag den 29. juni. Virksom til det sidste var dr. Toldberg som så ofte før rejst til England for at studere i biblioteker og samlinger. En ny bog om den islandske digter Jóhann Sigurjónsson havde han lige afsluttet, og nye store opgaver ventede ham. Han faldt midt i kampen.

Helge von Westen Toldberg blev født den 21. april I9I3 på Frederiksberg. Han blev student fra Frederiksberg Gymnasium I93 I, cand. mag. 1938 med dansk som hovedfag og engelsk som bifag og erhvervede Københavns Universitets guldmedalje i 1942.

Oprindelig var Toldberg vist mest tilbøjelig til at kaste sig over rent filologiske emner. Hans viden og indsigt $\mathrm{i}$ nordiske sprog og hans energiske medleven $\mathrm{i}$ den moderne filologis problematik pegede mod en indsats inden for den norrøne filologis rammer. Hans første videnskabelige merit var et udgiverarbejde, udgaven af Mikkel Hansen Fernskags digte, som han besørgede sammen med Mogens Kabel 1937. Hans sidste store filologiske indsats blev udgaven af Den Danske Rimkronike I-III I958-6I, der skulle sluttes med et endnu ikke udgivet kommentarbind. Det var også de filologiske problemer, der førte ham ind i Grundtvig-studiet med guldmedaljeafhandlingen, der foreligger $\mathrm{i}$ en noget ændret form $\mathrm{i}$ bogen: Grundtvig som filolog I 946 .

Forinden havde Toldbergs interesse for norrøn digtning, sprog og mytologi manifesteret sig $\mathrm{i}$ en lille bog: Det nordiske Element $i$ Johannes Ewalds Digtning i 943.

Arbejdet med Grundtvig som filolog gav Toldberg adgang til Grundtvig-arkivet, der lå uordnet og ofte kaotisk i de mere end 500 fascikler på Det kgl. Bibliotek. Der forestod her et umådeligt ord- 
nings- og opklaringsarbejde. Et af de problemer, der først måtte løses, var spørgsmålet om de forskellige papirers datering. Toldberg gik ikke af vejen for vanskelighederne og opstillede $i$ en afhandling $i$ Nordisk tidskrift för bok- och biblioteksväsen 1946 en række dateringskriterier for Grundtvigs håndskrifter $\mathrm{f}$. eks. papirsorter, vandmærker, ortografi, skrifttræk osv. Selv om senere forskning har revideret nogle af disse kriterier, hævder afhandlingen fremdeles sin plads som den første systematiske vejleder til klaringen af en af Grundtvig-arkivets vigtigste problemsider. Inden sin død nåede Toldberg i det sidste bind af registranten at samle hele sin omfattende viden om Grundtvig-arkivets papirsorter og de dateringsproblemer, som knytter sig dertil, i en stor og givende afhandling.

Det tjener Toldberg til megen ære, at han på et tidligt tidspunkt søgte samarbejde med de mange af hans nogenlunde jævnaldrende forskere, som enten ud fra filologiske, litterære, teologiske, pædagogiske, psykologiske eller historiske synspunkter arbejdede videnskabeligt med Grundtvigs person og livsgerning. Toldberg var en af de ivrigste for stiftelsen af Grundtvig-Selskabet af 8. september 1947 og valgtes til selskabets første sekretær. Han udførte her et helt utroligt arbejde og førte en vældig protokol, hvori så at. sige alle detaljer vedrørende selskabets første fire leveår er noteret ned.

Efter sin afgang som sekretær i I 95 I var han fremdeles forretningsudvalget til stor hjælp og nytte og holdt et vågent udkig med alt nyt, der dukkede op inden for Grundtvig-forskningen. Navnlig var det ham kært, når han kunne vinde nye proselytter for sagen og fange nye, unge forskere ind til gavn for studiet af Grundtvig.

Allerede inden stiftelsen af Grundtvig-Selskabet havde Toldberg i samarbejde med William Michelsen udkastet planerne til en udgave omfattende ikke blot de trykte, men også de utrykte værker af Grundtvig. Efter planen ville værket komme til at omfatte i 30 bind og blive en både meget dyr og langvarig historie. Toldberg forsonede sig aldrig med tanken om, at denne plan skulle opgives. Så sent som i dette år fremhævede han i en enquete i Vindrosen ønskeligheden af, at man snarest gik i gang med virkeliggørelsen af den store plan. En af begrundelserne herfor var tilstedeværelsen $i$ vor generation af en række kyndige Grundtvig-forskere. Hans alt for tidlige død understreger rigtigheden $\mathrm{i}$ og alvoren bag hans argumentation.

Man kan dele hans beklagelse over, at den store Grundtvig-udgave endnu blot er et smukt ønskemål, men set ud fra et strengt 
realistisk synspunkt, måtte en registrant af det vældige Grundtvigarkiv gå forud for den nævnte udgave. Denne registrant havde Helge Toldberg den lykke at se tilvejebragt som et $\mathrm{i}$ mange måder smukt resultat af et team-work blandt en generations Grundtvig-forskere. Og også som medarbejder ved registranten kom Toldberg til at yde en betydelig indsats.

Som forsker vil hans navn længst være knyttet til den store disputats: Grundtvigs symbolverden, der udkom i i $95^{\circ}$. Her gik han nye veje inden for den litteratur-videnskabelige forskning ud fra tanker, der i høj grad var inspireret af hans fortrolighed med moderne sprog- og litteraturforskningsteorier og hans kærlighed til norrøn poesi og mytedigtning. Det blev ikke nogen let læst bog, men et værk som forskningen i mange måder kan nyde gavn af. Han ejede vel ikke det musiske sind, der rent intuitivt kunne føre ham ind i tolkningen af den grundtvigske poesi, men han havde en helt ufattelig viden og en næsten hensynsløs energi, der blev drevet frem af en stor kærlighed til og beundring for N. F. S. Grundtvig.

Helge Toldberg vil blive savnet inden for Grundtvig-forskningen og som deltager i Grundtvig-Selskabets møder. Der var noget afvæbnende ved den ihærdighed, hvormed han førte sine ikke altid lige realisable ideer frem, og han var en mand, der ikke bar nag, selv om hans tanker kunne møde modstand. Hans navn vil leve længe inden for forskningen - og alle, der lærte mennesket Helge Toldberg nærmere at kende, vil værne om hans minde.

Gustav Albeck. 